\title{
Information Technology in Educational Management of Nepal
}

\author{
Hari Gopal Shrestha \\ National Computer Centre, Singhdurbar, Katmandu, Nepal
}

\begin{abstract}
This paper is divided into two parts. First the introduction touches very brielly on the geographical, economical and social status and use of computers in Nepal. The second part of the paper attempts to describes the use of Information Technology (IT) and its impact on the management of the secondary school, universities and Ministry of Education of Nepal. In conclusion, Nepal's policies regarding the use of information technology (IT) are presented.
\end{abstract}

Key Codes: H2.4; H3.3; J.6; K6.1

Keyword: Database Management System; Information Search and Retrieval; Computer -Aided Engineering; Project and People Management.

\section{INTRODUCTION}

Nepal is a mountainous country. It is a landlocked and sandwiched between the two large nations China in the north and India in the south, east and west. It is rectangular in shape with 147,181 sq. $\mathrm{km}$ of land in area. Of the total land area, about $78 \%$ is covered by snow mountains, high hills in the north and middle part of the country. Most of the flat lands lie in the southern part of the country. Nepal is predominantly an agricultural country. The cultivated land area is about $18 \%(36,535 \mathrm{sq} . \mathrm{km}$.) of the total land area. The population of Nepal is 18.5 million. Life expectancy at birth is 54.6 years. The literacy rate of Nepal is very low, it is only $39.6 \%$ and per capita income is US $\$ 170.00$ per annum.

\section{USE OF COMPUTERS IN NEPAL}

\subsection{Computer in Nepal}

Nepal first introduced computer technology in 1971, in connection with the processing of national population census data. IBM 1401, the second generation and medium sized mainframe computer, was used for data processing, table printing, statistical calculations, etc., of the population census. Only in 1984, the microcomputer was introduced in Kathmandu, Nepal. Since then the use of computers has been gradually increasing. At present, every government department and ministry in Nepal has been makes use of microcomputers. However, they still lack skilled manpower, and proper computer knowledge for using microcomputers according to their need. At the movement this technology (IT) is being used with middle level and low level manpower, to some extent. Similarly, in business, hotels, banks, airlines, travel agencies, some private boarding schools and campuses are being used microcomputers. Till now, the universities in Nepal have not introduced computer courses as such in the diploma and degree level although computers have already been used for management purposes. Very few campuses of the Kathmandu valley have started computer classes which take the form of an optional course or extra activities. In the Nepali cconomy, the demand for the skilled manpower is growing day by day. On the other hand highly skilled manpower in this field is leaving the country for better 
opportunities. The Nepalese computer working environment is not yet good enough. There is ample scope for improvement in this field. To improving management so as to satisfy customers and to upgrade the quality of work, the use of computer is being increased as far as possible.

\subsection{Devanagari Script}

In 1988, software experts of Nepal developed Nepali script ( Devanagari script) which can be used only in Macintosh. Only 10 percent of machines could be covered by this type of development. Now, by using windows package, in 1993 they have managed to develop Devanagari script in ASCII code for IBM compatible micro computers. This has increased the coverage to all types of computers having word processing facilitated. This has led to considerable increase in the number of desktop publishing houses, specially in Kathmandu. This has facilities such works as report writing, printing, preparation of data base, mailing list etc. The Ministry of Education, universities, schools and libraries are increasingly using this script making use of PC's.

\section{IT IN SCHOOL MANAGEMENT}

As per 1992 education statistics, there are 19,498 primary, 4,230 middle and 2,309 secondary schools, where altogether $38,89,847$ students are pursuing studies. Of these, there are about 800 boarding schools. About 50 of these boarding schools are providing education on computer subjects .Eleven of these boarding schools have been making use of micro computers for school management. The educational management activities include student and teacher's record keeping, research and development, examination result processing, question and answer designing, mailing list storing, account keeping, word processing, secretarial service, etc.

At Kathmandu, there are more than ten small private software houses. Among them three have prepared educational package, which contains student record keeping, pay roll, examination result processing, quarterly and yearly student evaluation, quiz boxes, etc. . At cheap price they are selling it in some schools. The buyer school have started using it .

\section{IT IN UNIVERSITIES MANAGEMENT}

\subsection{Tribhuvan University}

There are three universities in Nepal : Tribhuvan University (TU), Sanskrit University (SU) and Kathmandu University (KU). Tribhuvan University is the oldest university in Nepal. Under this university, there are many Institutes such as Institute of Engineering, of Forestry, of Medicine, of Education, of Management, of Humanity and of Science \& Technology. These institutes have altogether 209 campuses (i.e. 72 Government and 137 private), where 154,528 student pursue their studies. In most of these institutes microcomputers have been used as a tool for management, but they are used only in central offices. Here, the activities include record keeping, statistical tabulation, research and development, planning, word processing, examination result processing of certificate and Diploma level of Arts and Commerce faculty etc. Apart from this, the mark sheet certificate printing work general mark ledger book printing etc. have also been done. Tribhuvan university is also running a tailor-made application package for the provident fund of TU administrative staff and teachers. 


\subsection{Institute of Engineering}

This campus has 2014 students and 350 teachers. At present, the students are studying on the Intermediate of Engineering (IE) and Bachelor of Engineering (BE) level. The campus has the five departments: Civil Department, Architecture Department Mechanical Department, Electrical Department, Electronic Department. Each faculty has microcomputers to support their administrative and teaching staff. To support the management, at present, 15 microcomputers are in use, and 30 for the practical class.

For the central administration of this campus, a 386 model IBM compatible computer is on stand by, which can print lists of scholarship (25\%) and (20\%) holder students a sample of computer printed list of students getting scholarship and freeship is given in Figure-I. It can also print the evaluation of teachers and students, in terms of marks, employment, subject, department, faculty, seniority, and sex.

For management purposes, this computer can help in selecting a list of students eligible for scholarships for study leave, promotion, demotions and other personal information. It can produce status of provident fund, income tax and staff pay roll. It can be used for Devanagari word processing as well. An example the Devanagari scripts in given in Figure-I.

\subsection{Institutes of Medicine}

At present, each department of the Teaching Hospital (TH) Institute of Medicine has micro computers to use as a supporting tool for management, in preparing staff pay roll, and income tax output print, Word processing and desktop publishing in English and Devanagari script. Nursing campus of TH has created a complete database of the staff, teachers and students. This database is used for scholarship, promotion, study leave, training, mailing, list and other purposes. Entrance examination processing of 1450 new applicants to the Medical Institute has also started from the 1994 session. Teaching Hospital management is running the following 11 health - related projects. The management of each project is using IT tools. The projects are the following:
a) Corneala Infection Project.
b) South Asian Cataract Management Project
c) Family Health Project
d) Health Learning Project
e) Health Development Project
f) Field Education Project
g) Library Project
h) Research Project
i) Mental Health Project
j) Ear, Nose and Throat Research Project
k) JCA Project

\subsection{Library}

The computer has been used in Tribhuvan University (TU) central library for preparing a bibliographic data base of about 200,000 books, magazines, periodicals, and papers, for book registration, reservation, issue and receipt. To carry out these activities, the library is using CDS/ISIS software package developed by UNESCO. This package was first used by TU central library only in 1993.

\subsection{Centre for Educational Research \& Development}

Centre for Educational Research \& Development (CERED) is running TU 10+2 TU's project so as to support planning division and to implement a $10+2$ system in Nepal. This centre is using the computer for carrying out secondary school space survey, teacher availability, feeder school students survey, teachers work-load survey, teachers personnel record keeping, etc. After completion of these surveys, the results (statistical data) are going 
to be used for planning and implementation of a $10+2$ educational system which is a new system for Nepal. The Ministry of Education, Culture and Social Welfare is waiting for the report of these surveys so as to pinpoint the centres and potential areas for $10+2$ classes. Thus, IT plays an important role in plarning.

\subsection{Kathmandu University}

Kathmandu University was established in 1992. and presently 1003 students are enrolled in it. Here classes are being run under such faculties as Science \& Technology, Management, and the Humanities. Altogether 22 microcomputers have been used in computer science classes. Fourteen computers have been operating to carry out management work of this university. Here also activities include university planning, project control, simulation, record keeping, research and development, account keeping, examination result processing, secretarial services, etc. In this way, information technology has been used to assist top and middle level management of Kathmandu University. This technology has not yet been introduced in Sanskrit University. But at present, having put Devanagari script in ASCII, the Sanskrit University is also considering the introduction of the microcomputer. The characters of the Sanskrit language are based on Devanagari script. An example of Devanagari script used at the Engineering Campus is given Figure-II.

\section{IT IN MINISTRY OF EDUCATION, CULTURE AND SOCIAL WELFARE}

\subsection{Ministry of Education}

The Ministry of Education, Culture and Social Welfare has prepared an educational database on various levels namely on the national, regional, zonal and district level. It has published data such as number of schools by development and geographic region. It has also prepared primary, lower secondary and secondary level enrollment and number of teachers by development and geographic region. Students /school and teacher ratios, higher education enrollment, sector wise distribution of education, budget, etc., are also prepared and published by means of the computer. Other activities at the national level include educational research and development, simulation, planning, tabulation, word processing, etc. Result processing of about 160,000 students who took the school leaving certificate examination in 1993, has been carried out at 208 examination centers covering the whole country. Based on the result, school evaluations at the national, regional, zonal and district level are carried out by the Ministry of Education, Culture and Social Welfare. Apart from this, computers are also used for mark sheet printing, general mark ledger book printing, question paper selection, design and printing pre-SLC examination ledger book printing, etc., which have helped quite a lot in planning and arranging examinations. Certificate printing is underway. Because of the use of computer in the preparation of educational database, the Ministry Education has become more able to control, manage supply and provide the facilities in time. In 1994 the Ministry of Education Culture, and Welfare is carrying out pre and post final examination result processing of $10+2$ classes using the computer as a test run. In 51 districts for 18,000 students, they have opened more than 51 examination centres.

\subsection{Janak Educational Material Centre}

Janak Educational Material Center is functioning as a national publishing house on behalf of his Majesty's Government of Nepal. At present, it is printing more than one million books on over a hundred subjects for the primary, lower secondary and secondary schools every year. For this, the center is making use of computers in such activities as computer design, screen design, word processing, editing, etc. 


\subsection{Department of Archaeology}

The Department of Archaeology has five powerful microcomputers, which have created a National Archaeological Bibliographic database which has more than one million records Similarly, the department is producing microfilms of historical and old documents. So far, they have produced more than 500,000 of these. In this project the German government is helping the department.

The National Library of Nepal has more than 100,000 books, magazines and periodicals. Using a the CDS/ISIS package, they are producing an-up-to-data bibliographic database. This library is run by the Ministry of Education, Department of Archaeology. More than 40 other libraries are also using the CDS/ISIS package which has made it very convenient to handle and manage library work in tracing and classifying books on different subjects. In Madan Library, located in Patan, Devanagari script has been used for creating a database and for word processing. This is an important step in the development of computer usage in IBM pc.

\section{IMPACT OF IT ON EDUCATION MANAGEMENT}

\subsection{Education management}

Like other sectors, educational management is also affected by Information Technology (IT). The teachers, educational administrators and experts, who are using IT tools at present, have become more capable, more reliable and more logical. Their working style has changed. So at present, the impact of IT in Nepal has been positive. This has motivated some private schools, campuses and private organizations and they have accordingly started using micro computers to back up their management according to their capacity and needs.

\subsection{Problems}

There are some problems that need to be tackled urgently. Firstly, there is a lack of knowledge on the part of senior officials regarding IT use in management. Secondly, there is a considerable lack of well-trained manpower. Apart from this, there is felt to be a large budget constraint for buying necessary hardware and software. Last but not least is a lack of development of computer- friendly culture and environment.

\section{CONCLUSION}

The use of Information Technology in the management of daily, monthly and annual activities of schools, campuses, universities and the Ministry of Educational is gradually increasing, albeit on a limited scale. If this technology, which is expected to expedite allround development of the country, could be used for education management, it would add momentum to education development. Development of education will bring major and prompt changes in the mental, economic, social and scientific spheres. It is also expected to augment the all-round development of nations and the of world as a whole. Nepal has a strong belief in the tremendous role played by Information Technology in the enhancement of development. 


\title{
REFERENCE
}

HMG, Ministry of Education, Culture and Social welfare, Planning Division, Manpower and Statistics section, Keshar Mahal, Kathmandu, Nepal. Education Statistics of Nepal 1988-92 AD.

\section{Figure-I}

Computer printed list of students getting Stipend and freeship.

\section{DETAILS OF SCHOLARSHIP \\ DIPLOMA IN ARCHITECTURE ENGINEERING \\ 2ND YEAR 1ST PART \\ (COMMENCED ON 5TH JESTHA, 2049)}

\begin{tabular}{llllll} 
S.NO. & BATCH & CRN & NAME OF STUDENTS & \multicolumn{2}{l}{ SCORE FSUB STATUS REMARKS } \\
1. & 2047 & 324 & HARI DANGOL & 503 & STIP \\
2. & 2047 & 314 & BINDU SHRESTHA & 494 & STIP \\
3. & 2047 & 365 & SURESH KR-RAUT & 473 & STIP \\
4. & 2047 & 340 & PUSPA SHANKER SHRESTHA & 472 & STIP \\
5. & 2047 & 325 & YADAV PD. MAINALI & 467 & STIP \\
6. & 2047 & 321 & HOM NATH POUDYAL & 467 & STIP \\
7. & 2047 & 334 & MAMATA POUDYAL & 429 & FREE \\
8. & 2047 & 306 & RUPAL SHRESTHA & 440 & FREE
\end{tabular}

\section{Figure-II}

A sample of a notice, for the students of the Campus in Devanagari script.

\author{
इन्जिनियरिंग अध्ययन सस्थान \\ पुल्चोक क्याम्पस \\ सूचना \\ २०४१/३/२५ मा
}

आगामी वर्ष २०५१ श्रावण १ गते देखि यस क्याम्पसमा अध्ययन गरी रहेका सिभील डिपार्टमेन्ट, आर्किटक्वर डिपार्टमेन्ट, मेकानिकल डिपार्टमेन्ट, इलेक्ट्रीकल डिपार्टमेन्ट र इलेक्ट्रोनीक डिपार्टमेन्टका सम्पूर्ण विब्यार्थिहरूलाई उनीहरको ३ वर्ष पदाई भित्र कुन एक सेमेष्टरमा कम्युटर कोर्ष लिनुपर्ने गरीएको ब्यहोरा यो सूचना द्वारा जानकारी गराइन्छ। 